\title{
THE EFFECT OF NON-FINANCIAL COMPENSATION ON WORK PRODUCTIVITY THROUGH WORK SATISFACTION AS INTERVENING VARIABLE IN EMPLOYEES OF REGIONAL GOVERNMENT BUSINESS AGENCY OF EAST JAVA PROVINCE: A STUDY AT PT KASA HUSADA WIRA JAWA TIMUR
}

\author{
Thamrin Adam Syarief ${ }^{1 *}$, Suaedi Falih ${ }^{2}$, Windijarto ${ }^{3}$ \\ ${ }^{1}$ Master of Human Resource Development, Postgraduate School, University of Airlangga, \\ Indonesia \\ ${ }^{2}$ Department of Public Administration, Faculty of Social and Political Science, \\ University of Airlangga, Indonesia \\ ${ }^{3}$ Department of Management, Faculty of Economic and Business, University of Airlangga, \\ Indonesia \\ *E-mail: adamsyariefthamrin@gmail.com
}

\begin{abstract}
The main objective of good human resource management within an organization or company is achieving optimal work productivity. So, to realize the goal of good human resource management is not just to provide wages in the form of money (financial), but the provision of good non-financial compensation also plays a fairly strong role in giving the impact of employee contributions in a company. So, this research was conducted to analyze and determine the effect of non-financial compensation on work productivity through job satisfaction as an intervening variable for employees of PT Kasa Husada Wira East Java. This research uses a quantitative approach involving 100 respondents who are employees of PT Kasa Husada Wira East Java. The results of this research are that there is an indirect influence between non-financial compensation on work productivity through job satisfaction variables as an intervening variable as indicated by the indirect effect value of $0.097(<0.5)$, which means that job satisfaction is an intervening variable that influences the relationship between compensation non financial to work productivity. so, in this study, the variable of job satisfaction as an intervening variable has a full effect (total).
\end{abstract}

\section{KEY WORDS}

Non-financial compensation, work, productivity, job, satisfaction.

The main problem that is of concern in profit organizations such as companies is the problem of 'work productivity'. Work productivity is the result of a good human resource management process. In good management of resources, high productivity will certainly be followed. Work productivity problems are a hot topic when industry and business competition is getting tighter and more competitive. Managing human resources as a strategy for determining the pace and growth of companies has a goal of increasing work productivity.

Anoraga (1992) explains, there are factors that are considered influential in the company's work productivity, these factors are: (1) Interesting work; (2) Good or decent wages; (3) Security and protection in work; (4) appreciation or self-actualization in work; (5) A good working environment and atmosphere; (6) Promotion in a career; (7) A sense of involvement in organizational activities; (8) Management's understanding and sympathy for personal problems; (9) Leadership loyalty to the worker, and; (10) Work discipline. So, to achieve work productivity, financial compensation is not the main key, there are many things that workers in the company must obtain and have a stronger psychological and emotional influence as explained by Anoraga. Non-financial compensation has a strong role in increasing work productivity, as explained by Handoko (2011, p. 155) which states that one way of management to improve work performance, motivation and job satisfaction is through providing compensation, both financial and nonfinancial.

Handoko (2011) also explained that job satisfaction is an indicator that also influences and experiences an increase when the implementation of non-financial compensation is 
done well. Job satisfaction has a strong enough role in achieving work productivity. Job satisfaction is interpreted as a comfortable feeling of employees in carrying out or facing their work within the company, job satisfaction itself is also an important factor in human resource management activities because it deals directly with employee behavior such as stress, depression, turnover, and attendance (Brown, 2010, p. 923). The compensation system, especially non-financial compensation is a full policy of company management. But, consideration and policy decisions for granting compensation must be considered as something that is important and supports work productivity.

Work productivity problems are experienced by almost all companies, not least by PT Kasa Husada Wira East Java (PT KHWJ) which is a subsidiary of PT Panca Wira Usaha, one of the holding companies which are also a Regional Owned Enterprise of East Java Province. PT KHWJ's productivity experienced a fairly volatile dynamic from year to year, from the data gathered, the company's total sales in 2017 (IDR 20,156,321) decreased significantly compared to 2016 (IDR $22,624,271$ ), the year 2017 is $25 \%$ below the company's target and $11 \%$ below the 2016 achievement. In previous years, the sales figure also moved quite volatile, in 2014 for example, which was at IDR 23,491,740 then decreased in 2015 in the position of IDR $20,739,239$. The productivity problem which is also moving quite dynamically can also be seen in the data compiled from the Production Department of PT KHWJ which states that in 2017 it produces 43 tons of cotton, far enough below the achievement of cotton production in 2016 which reached 57 tons. The gauze production in 2017 is in the number 737,937 m2 (non-sterile) and $921.134 \mathrm{~m} 2$ (sterile). This is also below the production value in the previous year which reached 1,538,905 $\mathrm{m} 2$ (non-sterile) and $829,067 \mathrm{~m} 2$ (sterile). The decline in productivity in the company PT KHWJ can be caused by several things such as; factors beyond the control of the company such as market conditions, but can also be caused by human resource problems within the company. PT KHWJ itself is a medical equipment company that has the main production of cotton and sterile or nonsterile gauze, this company is one of the companies with the best performance and contribution among other subsidiaries under PT Panca Wira Usaha, therefore, PT Panca Wira Usaha successively also ranked third in BUMD with the highest contribution to East Java Province's Original Revenue after Bank Jatim and Bank Perkreditan Rakyat UMKM Jatim.

This research has several research questions which are referred to as the formulation of the problem in the research, including (a) Is there an effect of non-financial compensation on job satisfaction ?; (b) Is there an effect of job satisfaction on work productivity ?, and; (c) Is there any effect of non-financial compensation through job satisfaction on work productivity? Meanwhile, this research was conducted to test, analyze and determine the effect of non-financial compensation on work productivity through job satisfaction as an intervening variable.

\section{LITERATURE REVIEW}

Effect of Non-Financial Compensation on Work Productivity. One of the things that are quite influential and contributes to work productivity is the provision of compensation, in this case, non-financial compensation which according to Anoraga (1992) has several factors other than merely providing financial wages or compensation. The worker will issue the ability and a large amount of effort he has if he feels that what he has done before has produced appropriate rewards or rewards (John and Smith, 2014). In addition to salaries, bonuses and incentives, various other things such as work environment, work equipment, opportunities and opportunities for promotion, reward, or relationship between superiors and subordinates are important things that have a strong role for the emotional and psychological workers themselves. the things related to non-financial compensation have a strong enough impact and role on the contribution of workers to the company (Flippo: 1984), then automatically, non-financial compensation as one of the strategies in managing human resources within the company. The research that was conducted by Roihatul Musyafi (2017) with the title "The Effect of Financial and Non-Financial Compensation on Work Productivity 
of PT PLN employees in the Service Area and Malang Network" shows that employee work productivity is significantly affected by non-financial compensation. The results of this research are reinforced by the data on respondents' characteristics which are dominated by the productive age workforce, which is 20 to 30 years with a percentage of $61 \%$ of the total $100 \%$. The non-financial compensation that is quite influential, among others, is the factor of the work itself (suitability, interest, etc.) and the work environment that is quite dominant among the variables used. This research also concluded that at the productive age of work employees are considered more in need of decent and good work facilities to support their work so that employee work productivity can increase.

The Effect of Non-Financial Compensation on Job Satisfaction and the Effect of Job Satisfaction on Work Productivity. In terms of human resource management and efforts to increase work productivity, in addition to compensation that has been properly obtained by workers, job satisfaction factors should also get the attention of the company. Job satisfaction itself is an important factor in increasing work productivity in the company as explained by Hasibuan (1994: 222) which explains that job satisfaction is the psychological and emotional attitude of workers in the face of the work they do. Luthans (2006) explains, there are several indicators that are described as dimensions of job satisfaction, among others; the work itself; payment; promotion opportunity; supervision or leadership (boss), and; colleagues or colleagues. Some previous studies have shown that there is an influence between the implementation of non-financial compensation on job satisfaction, such as the research conducted by Recha Putri Etichasarie, et al (2016) with the title "Effect of NonFinancial Compensation on Job Satisfaction and Intention To Leave Java Bali Gresik Generation unit) "which shows the results that Non-Financial Compensation has a significant effect on Job Satisfaction in accordance with the path test results coefficient value 0.671 and significance 0,000 which means there is a significant effect between non-financial compensation on job satisfaction.

Then, several previous studies also showed a significant relationship between job satisfaction and work productivity, including research conducted by Caffery Geraldo Supit, FAO Pelleng and Kalangi with the title "The Effect of Job Satisfaction on Employee Productivity at PT Astra International Daihatsu - DSP Malalayang ". The results of their research stated that from the number of respondents as many as 30 people concluded that, Job Satisfaction has a minimum value of 45 , and a maximum value of 59 with an average value of 51.97 and has a standard deviation of 3.926 . Then, for work productivity variables has a minimum value of 36 and a maximum value of 42, with an average value of 39.03 and standard deviation of 1.991. Based on the results of the statistical calculation, it is known that between job satisfaction and work productivity has a significant relationship and the existing relationship is considered to be quite strong.

\section{METHODS OF RESEARCH}

This research uses a quantitative approach that is applied to test theories and hypotheses through measurement of variables using statistical counts and data analysis, the population in this research are all employees of PT Kasa Husada Wira Jatim totaling 130, and the sample set is a total of 130 employees, then sample determination applies the total sampling method which, according to Sugiyono (2007) is a sampling technique that is the same as the total population of the object under research. There are several research variables that are measured, including independent variables namely non-financial compensation $(X)$ or also called the independent variable, the dependent variable is work productivity $(\mathrm{Y})$ or also called the dependent variable, and the intervening variable namely jobs satisfaction.

There are data collected in this research, the data are primary data and secondary data. Primary data according to Sani and Maharani (2013: 183) are data obtained directly from respondents, in this research the data are in the form of questionnaires or questionnaires with data collection techniques in the form of distribution of questionnaires arranged in a structured manner so that answers and accurate responses can be obtained 
from respondents. Then, secondary data according to Sani and Masyhuri (2010: 194) is research data obtained indirectly or through media and other intermediaries, in this research, the data is in the form of company documents and information and other literature relating to the company and research conducted.

\section{RESULTS AND DISCUSSION}

The results of the instrument test, including validity test and reliability test are known to be valid, to test the validity of this is indicated by the acquisition of a correlation value that is greater than r-table $(0.195)$ so that all items from each variable are declared valid, this is similar to stated by Augusty Ferdinand (2006) which explains that if r-count is positive and rcount is greater than $r$-table, then the variable is valid. Whereas, for reliability testing, according to Nunnally (in Imam Ghozali, 2006) explaining a variable can be said to be reliable if it provides a Cronbach Alpha value $>0.60$. In the reliability test in this research, it is known that the value of Cronbach Alpha for each variable tested includes variable $X$ of 0.902 (Valid), variable Z of 0.914 (Valid) and variable $Y$ of 0.863 (Valid).

In this research, the characteristics of respondents involved in the research process, among others, on the aspect of sex, there were 52 male respondents involved or equivalent to $40 \%$ and there were 78 female respondents involved or equivalent to $60 \%$ with data on the age of respondents divided into 4 (four) clusters, the first cluster aged 26-30 years which amounted to 27 people or equivalent to $21 \%$, the second cluster aged $31-45$ years which amounted to 57 people or equivalent to $44 \%$, the third cluster with a number of $46-50$ years amounted to 30 people or equal to $23 \%$ and the fourth cluster is the age above 50 years with a number of 16 years or equivalent to $12 \%$. The majority of employees at PT Kasa Husada Wira Jatim have a working period of over 10 years with a number of employees working over 10 years totaling 95 people or $73 \%$, while employees with a period of 5 to 10 years amount to 35 people or $25 \%$ with placement of organizational units divided into production units of 92 people or $71 \%$ and non-production units totaling 38 people or $29 \%$. The descriptive analysis in this research of the three variables shows the average value that represents the respondent's response to the question item which is a derivative of the per-variable indicator. Meanwhile, the results of the descriptive analysis can be seen in the table below:

Table 1 - The result of Descriptive Analysis

\begin{tabular}{|c|c|c|}
\hline Variable & Indicator & Mean \\
\hline \multirow{4}{*}{ Non-Financial Compensation $(X)$} & Level of work facilities & 4.00 \\
\hline & Level of program and policies & 4.09 \\
\hline & Level of the environment and work comfort & 4.11 \\
\hline & Level of management-employee relationship & 3.95 \\
\hline \multirow{5}{*}{ job satisfaction (Z) } & otal & 4.03 \\
\hline & Level of job & 3.94 \\
\hline & Personality & 3.99 \\
\hline & Wages and opportunity of career promotion & 3.80 \\
\hline & Supervisor & 3.72 \\
\hline \multicolumn{2}{|c|}{ Total } & 3.86 \\
\hline \multirow[t]{4}{*}{ Work Productivity $(\mathrm{Y})$} & Quality & 3.96 \\
\hline & \multirow{3}{*}{$\begin{array}{c}\text { Quantity } \\
\text { Time }\end{array}$} & 4.17 \\
\hline & & 4.1 \\
\hline & & 4.07 \\
\hline
\end{tabular}

Source: Primary Data, 2018.

The data presented in Table 1 above illustrates the results of descriptive analysis carried out on three variables, in the non-financial compensation variable having an average value of 4.03 with indicators of the level of facilities, work facilities and infrastructure (4.00), program level and company policy (4.09), level of work comfort or environment (4.11), level of supervisor and subordinate relations (3.95). In this nonfinancial compensation variable, the indicators that get the highest score are environmental indicators and work convenience, 
employees provide a fairly good response to the current work environment conditions, colleagues who support work solutions and work environment conduciveness. Whereas, for the job satisfaction variable, the average value is 3.86 with employment level indicators (3.94), indicators of personality or personality (3.99), wage indicators and promotion opportunities (3.80) and supervision or supervisors (3.72). The response is quite good in this variable seen in the personality or personality indicators of employees who feel they can get the chance of self-actualization in the job well, while the promotion and supervision opportunity indicators or supervisors get a response that is not too good, this is due to opportunities for employees to get opportunities promotion tends to have a long waiting period and is quite complicated, on supervisory indicators or supervisors, the majority of employees assess supervisors' technical skills and competencies need to be improved. In the work productivity variable, it is known that the average value at 4.07 with three indicators includes quality (3.96), quantity (4.17) and, timeliness (4.1). In this variable, the average respondent believes that what they have done is sufficient to meet the quality standards of the company, the value of the quantity and timeliness set.

Data analysis using path analysis models to test the research hypothesis on the three variables. In this research there are two hypotheses that will be tested and proven, the two hypotheses include: (1) Non-Financial Compensation has an influence on Work Productivity $(X-Y)$, and, (2) Non-Financial Compensation has an influence on Work Productivity through Satisfaction Work (XZY). So, it can be seen that path analysis models are as follows:

$\mathbf{e}_{1} \quad \mathbf{e}_{2}$

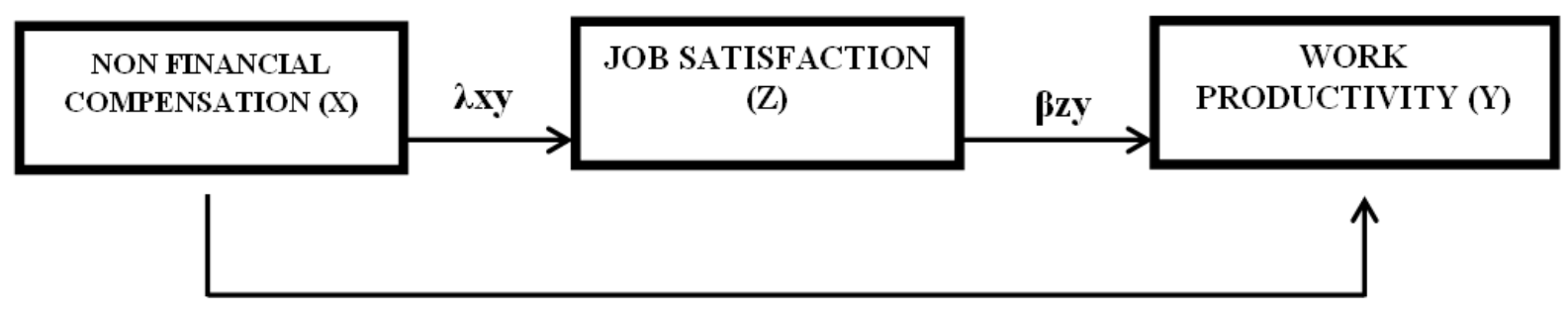

Figure 1 - Pathway analysis model

In the picture above, it can be seen, e1 is in the job satisfaction variable $(Z)$ which shows the number of variance variables of job satisfaction that are not explained by non financial compensation variables $(X)$, while for e2 is in the work productivity variable $(Y)$ which shows the variance work productivity variables that are not explained by non-financial compensation variables. From the application of path analysis model, it is known that the results of the influence path coefficient values between variables are as follows:

Table 2 - Results of Inter Variable Effect Line Coefficients

\begin{tabular}{|c|c|c|c|c|}
\hline \multirow{2}{*}{$\mathrm{n} / \mathrm{n}$} & \multicolumn{2}{|c|}{ Direct Effect } & \multirow{2}{*}{ In-direct effect } & \multirow{2}{*}{ Note } \\
\cline { 2 - 3 } & Beta & $P$ value & - & Not Significant \\
\hline $\mathrm{X}>\mathrm{Y}$ & 0.133 & 0.188 & - & Significant \\
\hline $\mathrm{X}>\mathrm{Z}$ & 0.732 & 0.000 & - & Significant \\
\hline $\mathrm{Z}-\mathrm{Y}$ & 0.224 & 0.025 & 0.097 & Significant \\
\hline $\mathrm{X}-\mathrm{Y}-\mathrm{Z}$ & - & - & 0 \\
\hline
\end{tabular}

Source: Primary Data, 2018.

Based on the table of the results of the path coefficient value influence between the variables above, the results of the influence between variables are as follows: (1) The value of the path coefficient of non-financial compensation $(X)$ on work productivity $(Y)$ is 0.133 with a significance value of $0.188(>0.5)$. this shows a negative sign, meaning that there is no unidirectional change in the non-financial compensation variable on work productivity; (2) The non-financial compensation variable $(X)$ path coefficient value on job satisfaction $(Z)$ is 0.732 with a significance value of $0.000(<0.5)$, this indicates a positive sign which means 
there is a change in the direction of explanation if the non-financial compensation variable increases, then Job satisfaction variables also increase, as well as vice versa; (3) The value of the path coefficient of work satisfaction variable $(\mathrm{Z})$ on work productivity $(\mathrm{Y})$ is 0.224 with a significance value of $0.025(<0.5)$. This indicates a positive sign which means there is a change in direction with the explanation if job satisfaction increases. also increases, and vice versa; (4) The non-financial compensation variable $(X)$ path coefficient value on work productivity variable $(Y)$ through job satisfaction variable $(Z)$ which is the result of multiplying the path coefficient value of $X$ to $Y$ and $Z$ to $Z$ is $0.097(<0.5)$ which show a positive sign. This means that there are unidirectional changes to these variables.

So, from the analysis and discussion above we can know that the first hypothesis which states that non-financial compensation has a significant effect on work productivity is not proven. Whereas, the second hypothesis which states that non-financial compensation significantly influences work productivity through job satisfaction is proven. Meanwhile, the explanation is illustrated by a complete path analysis model as presented in the figure below:

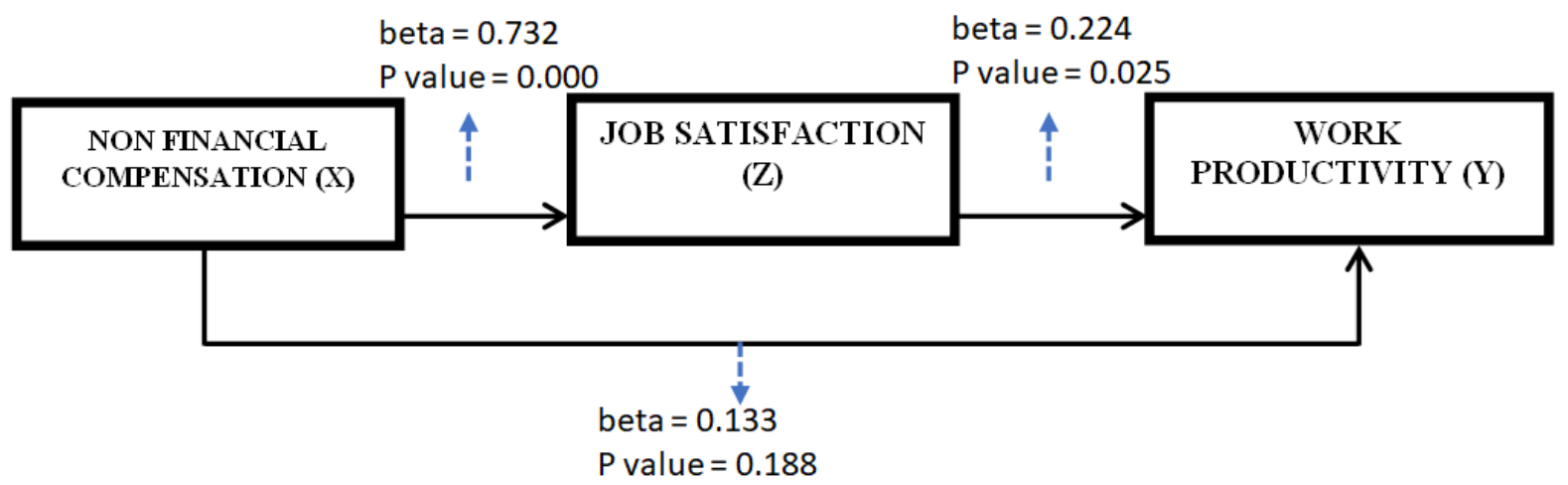

Figure 2 - Complete Path Analysis Model

Figure 2 above shows that non-financial compensation cannot directly influence work productivity, this is indicated by a fairly small number of direct effects on the two variables which are equal to 0.133 and sig values $0.188(>0.5)$. whereas, unidirectional changes are indicated by the non-financial compensation variable on the job satisfaction variable with a value of 0.732 and the sig value. $0.000(<0.5)$ and job satisfaction variables with a value of 0.224 and sig. $0.025(<0.5)$. Thus, we can know together that the variable $X$ which is nonfinancial compensation does not have a direct influence on the variable $Y$ which is work productivity, but non-financial compensation has an influence on work productivity through the variable $Z$ namely job satisfaction. So, job satisfaction $(Z)$ is proven to be an intervening variable.

\section{CONCLUSION AND SUGGESTIONS}

This research was conducted to determine the effect of non-financial compensation on work productivity and job satisfaction as an intervening variable. So, after the research, data analysis process, and discussion of research results, the results of the research can be concluded: (1) There is no direct influence between non-financial compensation variables (X) on work productivity $(\mathrm{Y})$ at PT Kasa Husada Wira East Java, p. This is indicated by the significance value of $0.188(>0.5)$, which means that this explains that non-financial compensation provided by the company does not directly influence the work productivity of the company's employees. So, thus the first hypothesis which states non-financial compensation has an influence on the work productivity of employees of PT Kasa Husada Wira East Java is not proven, and; (2) There is an indirect influence between the nonfinancial compensation variable $(\mathrm{X})$ on work productivity $(\mathrm{Y})$ through the job satisfaction variable $(Z)$ indicated by the indirect effect value of $0.097(<0.5)$ which means that there is a significant effect of non-financial compensation $(X)$ towards work productivity $(Y)$ through job 
satisfaction $(Z)$ as an intervening variable. So, thus the second hypothesis which states there is an influence between non-financial compensation on work productivity through job satisfaction as a proven intervening variable. Non-financial compensation variable on work productivity according to this research can only be said to have an effect if there is an intervening variable, in this case, is job satisfaction.

Based on the conclusions of the research, the management of the company should pay attention to several important things which are the most important aspects of good human resource management activities. The application of non-financial compensation, especially on indicators of facilities and completeness of supporting work, is considered important enough to create a climate and a good working atmosphere within the company for employees both physically and psychologically. The attitude, behavior, and feelings of employees in doing work are considered to have sufficient influence on the achievement of expected work productivity (Hasibuan: 1990). So if you look at the results of the research, there is a close relationship between giving non-financial compensation to job satisfaction, Luthans (2006) describes the dimensions of job satisfaction as an aspect that plays a fairly strong role in achieving good work performance and productivity.

\section{REFERENCES}

1. Cafry Geraldo Supit, F.A.O Pelleng, J.A.F Kalangi. (2017). Pengaruh Kepuasan Kerja Terhadap Produktivitas Kerja Karyawan PT Astra International Daihatsu DSO Malalayang. Jurnal Administrasi Bisnis Universitas Sam Ratulangi. Vol. 5 No. 1. Januari 2017.

2. Recha Putrie Etichasarie, Bambang Swasto Sunuharyo, Yuniadi Mayowan (2016). Pengaruh Kompensasi Non Finansial Terhadap Kepuasan Kerja and Intention To Leave pada Karyawan PT PJB UP Gresik. Jurnal Administrasi Bisnis (JAB). Vol. 40 No. 2. November 2016.

3. Roihatul Musyafi', Hamidah Nayati Utami, Yuniadi Mayowan. (2017). Pengaruh Kompensasi Finansial and Non Finansial Terhadap Produktivitas Kerja Karyawan - Studi Pada Karyawan PT PLN (Persero) Area Pelayanan and Jaringan Malang. Jurnal Administrasi Bisnis (JAB). Vol. 39 No. 2. Oktober 2017.

4. Anoraga, Pandji. (1992). Psikologi Kepemimpinan. Rineka Cipta: Jakarta.

5. Augusty, Ferdinand. (2006). Metode Penelitian Manajemen: Pedoman Penelitian untuk Skripsi, Tesis and Disertasi Ilmu Manajemen. Universitas Diponegoro: Semarang.

6. Brown, J.D (2010). The Self. Mc Graw-Hill: Boston.

7. Flippo, Edwin B. (1984). Personal Management. McGraw-Hill: New York.

8. Ghozali, Imam. (2006). Aplikasi Analisis Multivariate dengan Program SPSS (Edisi ke 4). Badan Penerbit Universitas Diponegoro: Semarang.

9. Handoko, T. Hani. (2011). Manajemen Personalia and Sumberdaya Manusia. Penerbit BPFE: Yogyakarta.

10. Hasibuan. S.P Malayu. (1994). Manajemen Perbankan. CV Haji Magum: Jakarta. 